\title{
The Effect of Post-grinding Heat Treatment of Alumina and Ag-Cu-Ti Braze Preform Thickness on the Microstructure and Mechanical Properties of Alumina-to-Alumina-Brazed Joints
}

\author{
Tahsin Ali Kassam, Hari Babu Nadendla, Nicholas Ludford, and Iris Buisman
}

(Submitted December 22, 2015; in revised form February 26, 2016; published online May 24, 2016)

\begin{abstract}
Alumina-to-alumina-brazed joints were formed using 96.0 and $99.7 \mathrm{wt} \% \% \mathrm{Al}_{2} \mathrm{O}_{3}$ and TICUSIL $^{\circledR}$ (68.8Ag26.7Cu-4.5Ti wt.\%) preforms of different thicknesses. Brazing was conducted in a vacuum of $1 \times 10^{-5}$ mbar at $850{ }^{\circ} \mathrm{C}$ for 10 minutes. Joint strengths were evaluated using four-point bend testing and were compared to flexural strengths of standard test bars. Post-grinding heat treatment, performed at $1550{ }^{\circ} \mathrm{C}$ for 1 hour, did not affect the average surface roughness or grain size of either grades of alumina but affected their average flexural strengths with a small increase for $96.0 \mathrm{wt} . \% \mathrm{Al}_{2} \mathrm{O}_{3}$ and a small decrease for $99.7 \mathrm{wt} \% \mathrm{Al}_{2} \mathrm{O}_{3}$. As the TICUSIL ${ }^{\circledR}$ preform thickness was increased from 50 to $100 \mu \mathrm{m}$, the average strengths of both 96.0 and $99.7 \mathrm{wt} \% \mathrm{Al}_{2} \mathrm{O}_{3}$ brazed joints improved. Joints made using 100- $\mu \mathrm{m}$-thick TICUSIL $^{\circledR}$ preforms predominantly consisted of $\mathrm{Cu}$-Ti phases which formed due to excess $\mathrm{Ti}$ in the interlayers and non-uniform Ag-rich outflow. Brazed joints of 96.0 wt.\% $\mathrm{Al}_{2} \mathrm{O}_{3}$ made using 100- $\mu \mathrm{m}$-thick TICUSIL $^{\circledR}$ preforms achieved an average joint strength of $238 \mathrm{MPa}$ with consistent failure in the ceramic.
\end{abstract}

Keywords advanced ceramics, alumina, brazing, heat treatment, joining, joint strength, preform thickness, TICUSIL $^{\circledR}$

\section{Introduction}

Alumina $\left(\mathrm{Al}_{2} \mathrm{O}_{3}\right)$ is the most cost-effective and widely used advanced ceramic material. Refractoriness, electrical insulation, wear and corrosion resistance makes alumina suitable for use in a wide range of applications, e.g., abrasives, vacuum feedthroughs, high voltage insulation, and protective linings. Exploitation of the desirable properties of ceramics in an industrial context often requires ceramic-to-metal joining. Ceramic-to-ceramic joining can improve the understanding of the weaker ceramic interface in the earlier stages of developing or refining a ceramic-to-metal system (Ref 1). In addition, the

This article is an invited submission to JMEP selected from presentations at the Symposium "Joining Technologies," belonging to the Topic "Joining and Interfaces" at the European Congress and Exhibition on Advanced Materials and Processes (EUROMAT 2015), held September 20-24, 2015, in Warsaw, Poland, and has been expanded from the original presentation.

Tahsin Ali Kassam, National Structural Integrity Research Centre (NSIRC), Granta Park, Great Abington, Cambridge CB21 6AL, UK Brunel Centre for Advanced Solidification Technology (BCAST), Brunel University London, Uxbridge, Middlesex UB8 3PH, UK; Hari Babu Nadendla, Brunel Centre for Advanced Solidification Technology (BCAST), Brunel University London, Uxbridge, Middlesex UB8 3PH, UK; Nicholas Ludford, Specialist Materials and Joining (SMJ), TWI Ltd, Granta Park, Cambridge CB21 6AL, UK; and Iris Buisman, Department of Earth Sciences, Cambridge University, Cambridge CB2 3EQ, UK. Contact e-mail: tahsin.kassam@affiliate.twi.co.uk. difficulty and expense in machining complex ceramic parts can be reduced through joining simpler shaped ceramic parts together.

Active metal brazing (AMB) is a single-step liquid-state joining process whereby a braze alloy that contains an active element, e.g., titanium (Ti) in silver-copper-titanium ( $\mathrm{Ag}-\mathrm{Cu}-$ Ti), can reactively wet a chemically inert ceramic surface (Ref 2 ). The undertaking of systematic experiments in ceramic joining is required to aid the understanding of the joining mechanism in order to optimize joint strength and reliability. Variables in the AMB of alumina include alumina and braze compositions, brazing atmosphere, peak brazing temperatures and dwell times, and heating and cooling rates. Factors affecting the determination of joint strength include parent material properties, alumina surface condition, specimen geometries, and testing methods.

\subsection{Post-grinding Heat Treatment}

Grinding of a ceramic can affect its surface roughness and may induce surface defects, both of which can adversely affect the flexural strength of alumina (Ref 3,4$)$. However, grinding is a necessary procedure which imparts dimensional accuracy to an otherwise defect-free but uneven as-sintered ceramic surface. Post-grinding heat treatment has been shown to improve the flexural strength of alumina (Ref 5).

The surface roughness of alumina has been shown not to affect the equilibrium contact angle achieved by $\mathrm{Ag}-\mathrm{Cu}-\mathrm{Ti}$ braze alloys (Ref 6). Surface defects (grain pull-out, microcracks, etc.), however, from grinding or otherwise, can act as failure initiation sites which can lead to premature joint failure (Ref 7). This can occur when thermally induced residual stresses (TIRS) which result from coefficient of thermal expansion (CTE) mismatch are generated at the alumina/Ag$\mathrm{Cu}-\mathrm{Ti}$ interface during cooling. Post-grinding heat treatment, 
applied to a range of alumina compositions, has therefore been used to improve the strength of alumina-to-alumina-brazed joints (Table 1).

\subsection{Ag-Cu-Ti Preform Thickness}

During brazing, diffusion of Ti toward the alumina/Ag-Cu-Ti interface leads to the formation of a reaction layer commonly reported as $\mathrm{Ti}_{3} \mathrm{Cu}_{3} \mathrm{O}(\mathrm{Ref} 8,9)$. The thickness of this reaction layer has been correlated to joint strength and can be controlled by the peak brazing temperature and dwell time (Ref 10). As the $\mathrm{Ti}$ concentration in the $\mathrm{Ag}-\mathrm{Cu}-\mathrm{Ti}$ alloy increases, reaction kinetics and wetting of alumina improve (Ref 6,11$)$. Therefore, the $\mathrm{Ag}-\mathrm{Cu}-\mathrm{Ti}$ braze volume, which determines the Ti concentration, may affect the reaction layer thickness and resulting joint strength.

Complete diffusion of $\mathrm{Ti}$ to the two faying surfaces in an alumina-to-alumina-brazed joint leads to the formation of a ductile Ag-Cu braze interlayer which can plastically deform to accommodate TIRS. In other work, it was reported that using $\mathrm{Ti}_{3} \mathrm{Cu}_{3} \mathrm{O}$ as a braze interlayer (lower CTE than Ag-Cu-Ti) could successfully produce alumina-to-alumina-brazed joints. These joints, however, were much weaker than those formed using Ag-Cu-Ti due to the absence of the ductile $\mathrm{Ag}-\mathrm{Cu}$ braze interlayer ( $\mathrm{Ref} 12$ ). Therefore, the $\mathrm{Ag}-\mathrm{Cu}$-Ti braze volume, which can alter the braze interlayer thickness, may also affect the resulting joint strength.

The Ag-Cu-Ti braze volume selected or braze preform dimensions are seldom reported in studies relating to the AMB of alumina, with a few exceptions (Ref 13). In most studies, the starting braze foil thickness is usually reported. In the formation of alumina-to-alumina-brazed joints made using Ag-Cu-Ti braze alloys, braze foil thicknesses ranging from 50 to $200 \mu \mathrm{m}$ have been reported (Fig. 1).

The aim of this study was to investigate the influence of post-grinding heat treatment and $\mathrm{Ag}-\mathrm{Cu}-\mathrm{Ti}$ preform thickness on the strength of alumina-to-alumina-brazed joints made using 96.0 and 99.7 wt.\% $\mathrm{Al}_{2} \mathrm{O}_{3}$.

\section{Experimental Procedure and Materials}

Two commercially available grades of polycrystalline alumina, Dynallox 96 (D-96, 96.0 wt.\% $\mathrm{Al}_{2} \mathrm{O}_{3}$ ) and Dynallox 100 (D-100, 99.7 wt.\% $\mathrm{Al}_{2} \mathrm{O}_{3}$ ), manufactured by CoorsTek Ltd, Crewe, UK, were used to produce test bars of two different geometries. All test bars were ground and chamfered according to ASTM C1161-13 (Ref 14). Standard test bars of both asground D-96 (D-96 AG) and D-100 (D-100 AG) had dimensions of $90 \times 8 \times 6 \mathrm{~mm}$ (Fig. $2 \mathrm{a}$ ). Short test bars with dimensions of $50 \times 8 \times 6 \mathrm{~mm}$ for D-96 AG and $48 \times 8 \times 6 \mathrm{~mm}$ for D-100 AG, were prepared for brazing trials (Fig. 2b).

Arithmetic mean surface roughness $(\mathrm{Ra})$ measurements were made using a Zeiss Surfcom 130A stylus profilometer. Three scans in both longitudinal $(L)$ and transverse $(T)$ directions were made at the mid-points of the outer surfaces of standard test bars $\left(R_{\text {outer }}\right)$ and at the faying surfaces of short test bars $\left(R_{\text {faying }}\right)$, as shown in Fig. 2 . In accordance with the ISO 4288 standard for Ra values between 0.1 and $2.0 \mu \mathrm{m}$, a roughness sampling length of $0.8 \mathrm{~mm}$ and an evaluation length of $4.0 \mathrm{~mm}$ were used.

A selection of both standard and short test bars were heat treated at $1550{ }^{\circ} \mathrm{C}$ for $1 \mathrm{~h}$ in a Carbolite HTC $18 / 8$ air furnace. This produced ground and heat-treated D-96 (D-96 GHT) and D-100 (D-100 GHT) test bars. Test bar surfaces that had been used for surface roughness measurements were maintained as free surfaces during the heat treatment following which surface roughness measurements were repeated, at the same initial locations $R_{\text {outer }}$ and $R_{\text {faying. }}$.

Alumina-to-alumina-brazed joints, whereby short test bars were brazed to themselves, were prepared by first arranging short test bars into butt-joint assemblies. For each joint assembly, a braze preform was placed between the faying surfaces of two short test bars. The braze preforms had dimensions of $7 \times 5 \mathrm{~mm}$ and were mechanically punched from 0.05 - and 0.1 -mm-thick foils of a commercially available active braze alloy TICUSIL ${ }^{\circledR}(68.8 \mathrm{Ag}-26.7 \mathrm{Cu}-4.5 \mathrm{Ti}$ wt.\%), manufactured by Wesgo Ceramics GmbH, Erlangen, Germany. Several joint assemblies were vertically supported in a bespoke stainless steel fixture, designed to allow uniform heating of each joint interface during brazing (Fig. 3). No additional load, other than the weight of the upper short test bar in each assembly, was applied.

Brazing was performed in a vacuum furnace at a pressure of $1 \times 10^{-5}$ mbar. A peak brazing temperature of $850{ }^{\circ} \mathrm{C}$ and a dwell time of $10 \mathrm{~min}$ followed a 10 -min isothermal soak at $750{ }^{\circ} \mathrm{C}$. Heating and cooling rates were 10 and $5{ }^{\circ} \mathrm{C} / \mathrm{min}$, respectively. Prior to each brazing cycle, the short test bars, braze preforms, and brazing fixture were all ultrasonically cleaned in acetone for 15 mins.

The mechanical strengths of standard test bars and brazed joints were evaluated using four-point bend testing at ambient room temperature. These tests were performed using a Hounsfield universal testing machine and a fully articulating

Table 1 Reported post-grinding heat treatments applied to alumina ceramics prior to active metal brazing

\begin{tabular}{|c|c|c|c|}
\hline \multirow[b]{2}{*}{ References } & \multirow[b]{2}{*}{ wt. $\% \mathrm{Al}_{2} \mathrm{O}_{3}$} & \multicolumn{2}{|c|}{ Heat treatment } \\
\hline & & Temp, ${ }^{\circ} \mathrm{C}$ & Time, min \\
\hline \multirow[t]{2}{*}{ Mizuhara et al. (1985) } & 99.5 & 1650 & 60 \\
\hline & 97.6 & & \\
\hline Mizuhara et al. (1989) & 99.5 & 1650 & 60 \\
\hline Cho et al. (1991) & 99.9 & 1500 & 30 \\
\hline Oyama et al. (1998) & 97.6 & 1500 & 180 \\
\hline \multirow[t]{2}{*}{ Hosking et al. (2000) } & 94.0 & 1575 & 120 \\
\hline & 99.8 & & \\
\hline Vianco et al. (2003) & 94.0 & 1575 & 120 \\
\hline Stephens et al. (2003) & Monocrystalline & 1575 & 120 \\
\hline
\end{tabular}




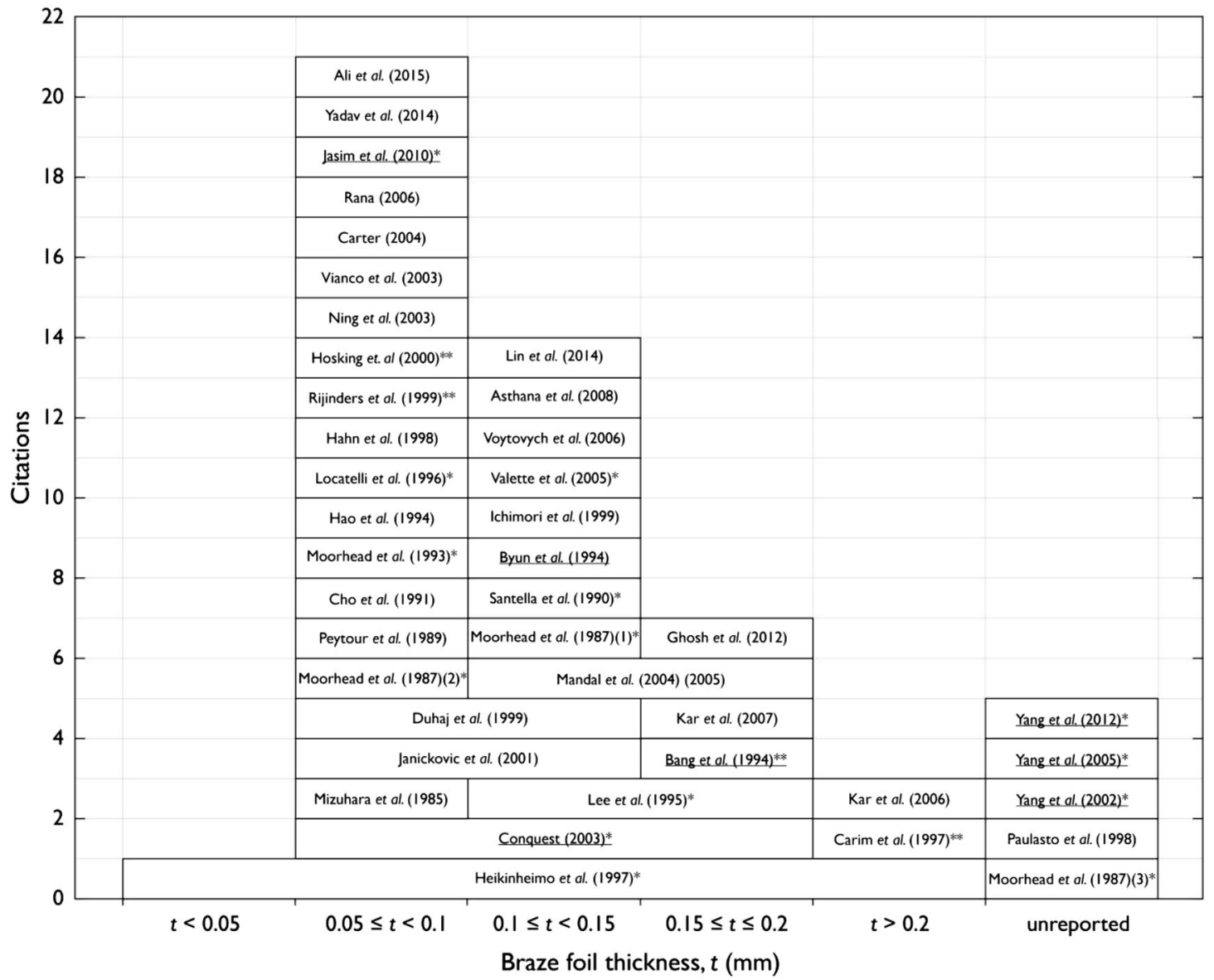

Underline denotes that the Ag-Cu-Ti braze alloy was applied in the form of a paste

* denotes that the $\mathrm{Ag}$-Cu-Ti braze alloy composition contained other alloying additions and/or other braze alloy compositions were also studied

** denotes that alternative braze alloy compositions were used e.g. $\mathrm{Cu}-\mathrm{Ti}$ or $\mathrm{Au}$-based, and no Ag-Cu-Ti braze compositions were studied

Fig. 1 Reported Ag-Cu-Ti braze foil thicknesses used in the formation of alumina-to-alumina-brazed joints

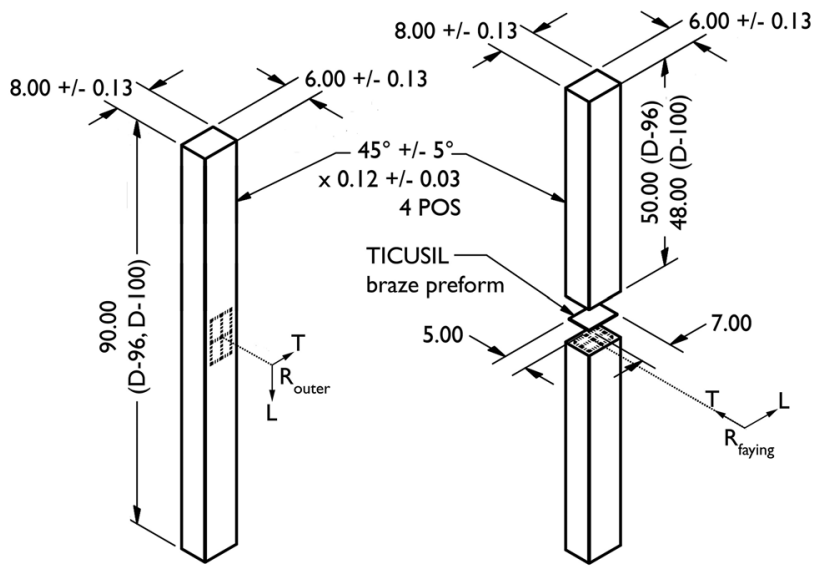

Fig. 2 Test bar geometries and Ra measurement positions (a) A standard test bar and (b) Two short test bars in a butt-joint assembly (all dimensions in $\mathrm{mm}$ )

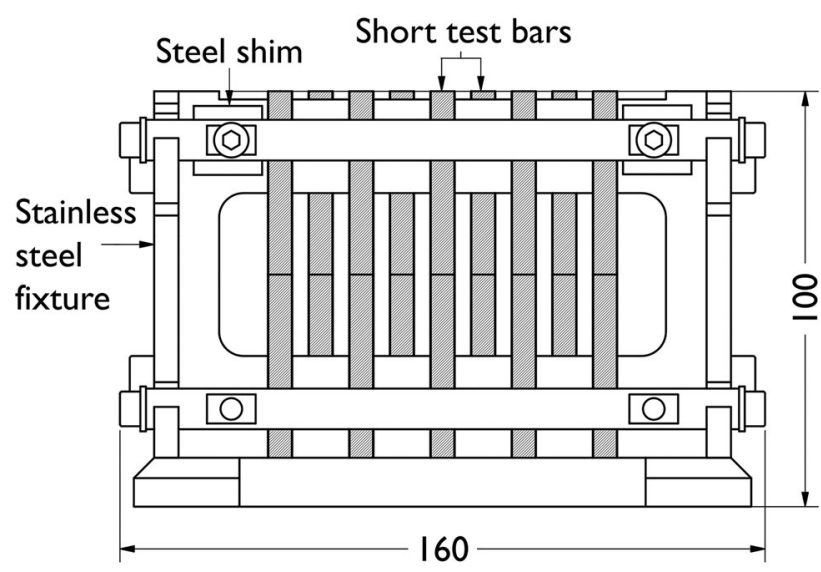

Fig. 3 Stainless steel fixture: 18 short test bars in butt-joint assemblies to form nine brazed joints (all dimensions in $\mathrm{mm}$ ) 
Table 2 Average phase compositions (wt.\%) of D-96 AG and D-100 AG

\begin{tabular}{|c|c|c|c|c|c|}
\hline Alumina & Density, $\rho, \mathrm{g} / \mathrm{cm}^{3}$ & $\mathrm{Al}_{2} \mathrm{O}_{3}$ & $\mathrm{SiO}_{2}$ & MgO & $\mathrm{CaO}$ \\
\hline D-96 AG & 3.75 & $96.24 \pm 0.81$ & $3.15 \pm 0.68$ & $0.55 \pm 0.12$ & $0.06 \pm 0.01$ \\
\hline D-100 AG & 3.87 & $99.65 \pm 0.08$ & $0.30 \pm 0.08$ & $0.03 \pm 0.00$ & $0.02 \pm 0.00$ \\
\hline
\end{tabular}

Analysis performed using EPMA and average values based on 10 measurements

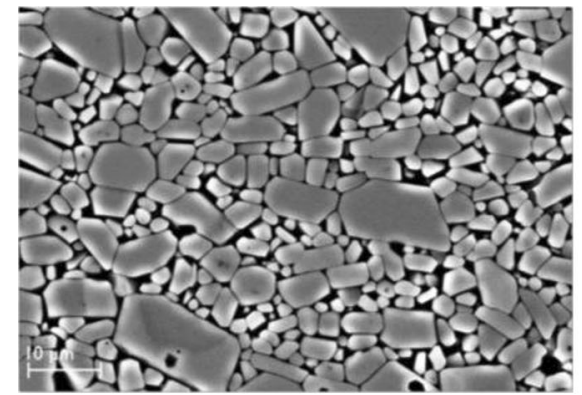

(a)

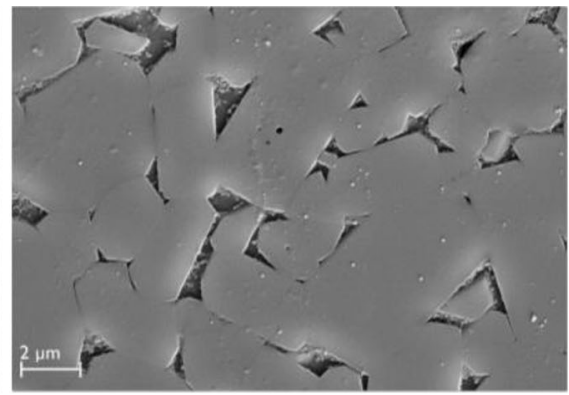

(b)

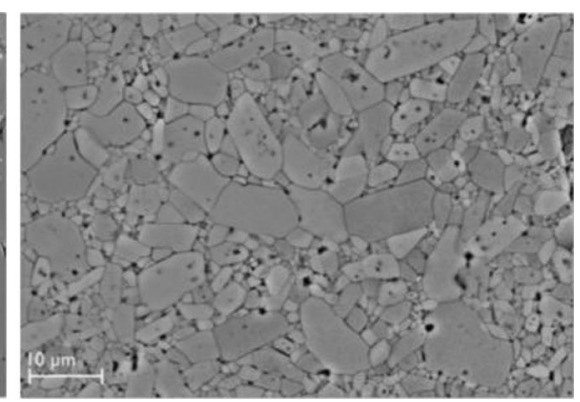

(c)

Fig. 4 (a) BSE image of D-96 AG polished and thermally etched at $1550{ }^{\circ} \mathrm{C}$ for $15 \mathrm{~min}$, (b) SE image of D-96 AG polished and chemically etched in 10 vol.\% HF solution for $20 \mathrm{~s}$, and (c) BSE image of D-100 AG polished and thermally etched at $1550{ }^{\circ} \mathrm{C}$ for $15 \mathrm{~min}$

four-point bend test fixture with an inner span of $40 \mathrm{~mm}$ and an outer span of $80 \mathrm{~mm}$ between 9-mm-diameter loading rollers. The loading rate was controlled at a crosshead speed of $1.0 \mathrm{~mm} / \mathrm{min}$.

Brazed joints were sectioned using an ATM Brilliant 220 precision cut-off machine with a wet diamond cutting disk. An ATM Saphir 560 with Rubin 520 head automatic grinding and polishing machine was used to prepare the sectioned samples for microscopy. Scanning electron microscopy (SEM), using both secondary electron (SE) and backscattered electron (BSE) detectors, and energy-dispersive x-ray spectroscopy (EDX) were performed using a Zeiss IIGMA field emission scanning electron microscope. Electron probe microanalysis (EPMA) was performed using a Cameca SX-100 with five wavelength dispersive spectroscopy (WDS) detectors. EPMA was carried out using a $15 \mathrm{kV}$ beam, $40 \mathrm{nA}$ current, and a nominal $1-\mu \mathrm{m}$ spot size. Each element was calibrated against a metal or oxide standard, and the oxides were calculated stoichiometrically. The trace elements such as silicon $(\mathrm{Si})$, magnesium $(\mathrm{Mg})$, and calcium (Ca) were counted for $120 \mathrm{~s}$ and silver (Ag), copper $(\mathrm{Cu})$, titanium $(\mathrm{Ti})$, and aluminum $(\mathrm{Al})$ were counted for $60 \mathrm{~s}$ to satisfy counting statistics over a large range of compositions expected across a traverse line scan from alumina into the Ag$\mathrm{Cu}$-Ti braze alloy.

\section{Results and Discussion}

\subsection{Alumina Characterization}

Liquid phase sintered D-96 AG was composed of $96.0 \mathrm{wt} \%$ $\mathrm{Al}_{2} \mathrm{O}_{3}$ with $\sim 3.2$ wt.\% silicon dioxide $\left(\mathrm{SiO}_{2}\right)$ as the main secondary phase (Table 2). Thermal etching revealed a bi- modal grain size distribution. Small and rounded grains had an average grain size of $\sim 1.5 \mu \mathrm{m}$ and larger slightly elongated grains had an average grain size of $\sim 6.5 \mu \mathrm{m}$ (Fig. 4a). Chemical etching of D-96 AG in 10 vol.\% hydrofluoric acid solution showed the secondary phase distribution to be intergranular (Fig. 4b).

Solid-state sintered D-100 AG was composed of 99.7 wt.\% $\mathrm{Al}_{2} \mathrm{O}_{3}$. Thermal etching revealed a bi-modal grain size distribution. Small and rounded grains had an average grain size of $\sim 2 \mu \mathrm{m}$ and larger slightly elongated grains had an average grain size of $\sim 9 \mu \mathrm{m}$ (Fig. 4c). Trapped porosity was observed both within the grains and more prominently at the grain boundaries. D-100 had been solid-state sintered at $\sim 1650{ }^{\circ} \mathrm{C}$.

\subsection{Surface Roughness}

The average Ra values of two sets of 20 standard test bars in the $L$ direction were $0.61 \mu \mathrm{m}$ for D-96 AG and $0.52 \mu \mathrm{m}$ for D$100 \mathrm{AG}$. In the $T$ direction, the average $\mathrm{Ra}$ values were $0.67 \mu \mathrm{m}$ for D-96 AG and $0.63 \mu \mathrm{m}$ for D-100 AG. These results show that the average Ra values were higher in the $T$ direction than in the $L$ direction for both D-96 AG and D-100 AG by 10 and $20 \%$, respectively. This was due to the outer surfaces of standard test bars having been ground parallel to their $L$ axis. Furthermore, despite the fact that the same standard grinding procedure had been applied to both grades of alumina, the average Ra values were higher for D-96 AG than for D-100 AG in both the $L$ and $T$ directions by 17 and $6 \%$, respectively. The rougher surface of D-96 AG may have been due to the presence of a secondary phase.

10 standard test bars were randomly selected from each of the D-96 AG and D-100 AG sets of 20 standard test bars for heat treatment at $1550{ }^{\circ} \mathrm{C}$. The average Ra values of D-96 GHT 
and D-100 GHT showed a net change of just $0.2 \%$ in comparison to D-96 AG and D-100 AG, as a result of the heat treatment (Fig. 5a). Such a small change is within standard experimental error and as such no change was observed. The same trend was observed when measurements were taken at $R_{\text {faying }}$ (Fig. 5b). Post-grinding heat treatment was found not to affect the surface roughness of the test bars.

\subsection{Flexural Strength}

The average flexural strengths of sets of 10 standard test bars were $252 \mathrm{MPa}$ for D-96 AG (standard error = 4.8) and $265 \mathrm{MPa}$ for D-96 GHT (standard error $=5.25$ ). This represented a $5.2 \%$ increase in the average flexural strength of D-96 due to heat treatment (Fig. 6). This result appeared to be statistically significant and was consistent with other studies where the heat treatment of the as-received $96.0 \mathrm{wt} . \% \mathrm{Al}_{2} \mathrm{O}_{3}$ rods at $1500{ }^{\circ} \mathrm{C}$ led to an increase in the average flexural strength (Ref 15). In D-96 GHT, heat treatment at $1550{ }^{\circ} \mathrm{C}$ may have caused liquid phase formation which re-sintered and healed grinding-induced surface defects. In addition, if the CTE of the liquid phase was higher than that of adjacent alumina grains then clamping of grain boundaries may have also contributed to the increase in strength observed (Ref 16).

The average flexural strengths of sets of 10 standard test bars were $249 \mathrm{MPa}$ for D-100 AG (standard error = 3.85) and $228 \mathrm{MPa}$ for D-100 GHT (standard error $=3.85$ ). This represented an $8.4 \%$ decrease in the average flexural strength of D100 due to heat treatment. This reduction in strength of D-100 GHT was not due to grain growth as the bi-modal grain size distribution remained unchanged, despite the low concentration of magnesia (MgO) after the original sinter (Table 2). Resintering and healing of grinding-induced surface defects in D100 AG may not have occurred during the heat treatment which was conducted at $100{ }^{\circ} \mathrm{C}$ below the original sintering temperature. Instead, this heat treatment may have simply annealed any grinding-induced compressive residual stresses un-pinning surface cracks and degrading the strength of D-100 GHT (Ref 17).

Fractography revealed that failure was mainly initiated at the tensile surfaces of all standard test bars. This was consistent with other studies where fractography combined with confocal scanning laser microscopy and dye penetrant inspection showed that $85 \%$ of fractures in the flexural testing of alumina originate from surface defects (Ref 18). In other work, it was reported that failure originated from surface defects as opposed to volume defects in the flexural testing of alumina (Ref 5).

Fractography of D-96 GHT standard test bars showed that failure was mainly initiated from microstructural defects. This occurred at an increased failure load in comparison to D-96 AG, D-100 AG, and D-100 GHT standard test bars in which failure did not initiate from microstructural defects. Figure 7 shows an example of the failure origin in the highest strength D-96 GHT standard test bar (286 MPa). In this case, failure initiated from a weakly bonded sub-surface agglomerate approximately $20 \mu \mathrm{m}$ beneath the tensile surface. These results indicated that grinding damage may have been responsible for failures in all conditions, except for D-96 GHT, where failure occurred at higher loads but was initiated at microstructural defects. Further fractography analysis, however, is required.

\subsection{TICUSIL ${ }^{\circledR}$ Braze Foil Thickness}

The as-received TICUSIL ${ }^{\circledR}$ braze foil (Fig. 8a-c) showed a non-uniform distribution of $\mathrm{Ti}$ (Fig. 8b, A) sandwiched in an Ag-Cu eutectic microstructure (Fig. 8b, B). TICUSIL ${ }^{\circledR}$ is a composite preform consisting of a Ti core and a cladding of an $\mathrm{Ag}-\mathrm{Cu}$ alloy. It is typically manufactured by a rapid solidification process. $\mathrm{A} \mathrm{Cu}$-Ti phase characterized as $\mathrm{Cu}_{4} \mathrm{Ti}_{3}$ (Fig. 8b, C) was observed in regions tied to Ti. The average compositions of these phases are listed in Table 3.

\subsection{Microstructure of Brazed Joints}

3.5.1 TICUSIL ${ }^{\circledR}$ Preform Thickness: $50 \mu \mathrm{m}$. D-96 AGbrazed joints made using $50-\mu \mathrm{m}$-thick TICUSIL ${ }^{\circledR}$ preforms had an average brazed joint thickness of $25.9 \mu \mathrm{m}$ and an average reaction layer thickness of $1.7 \mu \mathrm{m}$. Similarly, D-100 AG-brazed joints made using 50 - $\mu$ m-thick TICUSIL ${ }^{\circledR}$ preforms had an average brazed joint thickness of $21.2 \mu \mathrm{m}$ and an average reaction layer thickness of $1.6 \mu \mathrm{m}$ (Table 4). Three phases were observed in the uniform microstructures of both D-96 AG and D-100 AG joints made using 50- $\mu$ m-thick TICUSIL ${ }^{\circledR}$ preforms. These were an Ag-rich phase (Fig. 9a, D), a Cu-rich phase (Fig. 9a, E), and a reaction layer phase. These microstructures observed were similar to those commonly reported (Ref 8,9$)$.
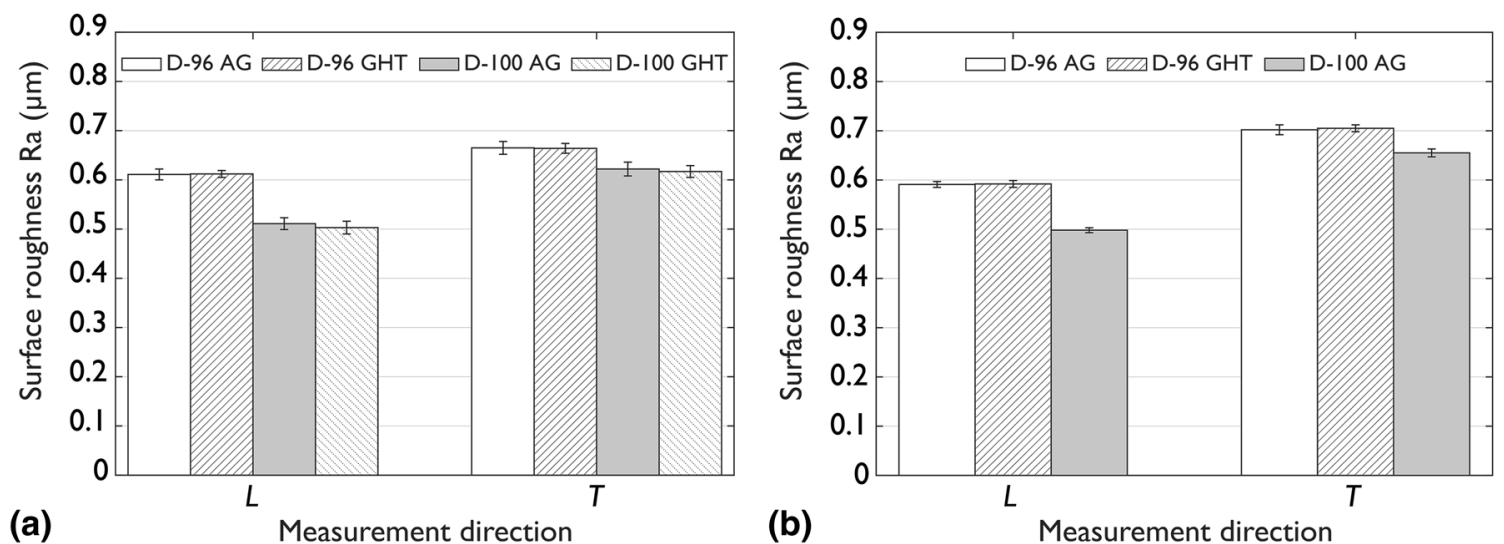

Fig. 5 Average $R_{\mathrm{a}}$ values $(\mu \mathrm{m})$ along longitudinal $(L)$ and transverse $(T)$ directions at (a) $R_{\text {outer }}$ and (b) $R_{\text {faying }}$ (Fig. 2) in D-96 AG, D-96 GHT, D-100 AG, and D-100 GHT standard and short test bars 
The reaction layer phase was characterized as $\mathrm{Ti}_{3}(\mathrm{Cu}+\mathrm{Al})_{3} \mathrm{O}$, using EDX, in both D-96 AG (Fig. 9a, F) and in D-100 AG (Fig. 9b, G) joints. The joint interfaces were also composed of a nm-thick TiO layer, on the alumina side of the interface. Full characterization of the $\mathrm{TiO}$ layer, however, was beyond the scope of this study. Based on the literature, the presence of $\mathrm{Al}$ in $\mathrm{Ti}_{3} \mathrm{Cu}_{3} \mathrm{O}$ is due to the reduction of alumina by $\mathrm{Ti}$ in the formation of $\mathrm{TiO}$ which enables chemical mass balance to be maintained. The $\mathrm{Ti}_{3} \mathrm{Cu}_{3} \mathrm{O}$ compound has a diamond cubic crystal structure with a lattice parameter of $11.24 \AA$ (Ref 19). It is hence referred to as an $\mathrm{M}_{6} \mathrm{O}$-type compound due to its metallic character which induces wetting, and has been shown to have an electrical resistivity of $5 \times 10^{-6} \Omega \mathrm{m}$, which is similar to that of $\mathrm{Ti}$ (Ref 20). Further work to more accurately characterize the interfaces of these joints is currently underway.

3.5.2 TICUSIL $^{\circledR}$ Preform Thickness: $100 \mu \mathrm{m}$. D-96 AG-brazed joints made using $100-\mu$ m-thick TICUSIL $^{\circledR}$ preforms had an average brazed joint thickness of $39.1 \mu \mathrm{m}$ and an average reaction layer thickness of $2.3 \mu \mathrm{m}$. Similarly D-100 AG-brazed joints made using $100-\mu \mathrm{m}$-thick TICUSIL ${ }^{\circledR}$ preforms had an average brazed joint thickness of $39.2 \mu \mathrm{m}$ and an average reaction layer thickness $2.2 \mu \mathrm{m}$ (Table 4). Five phases

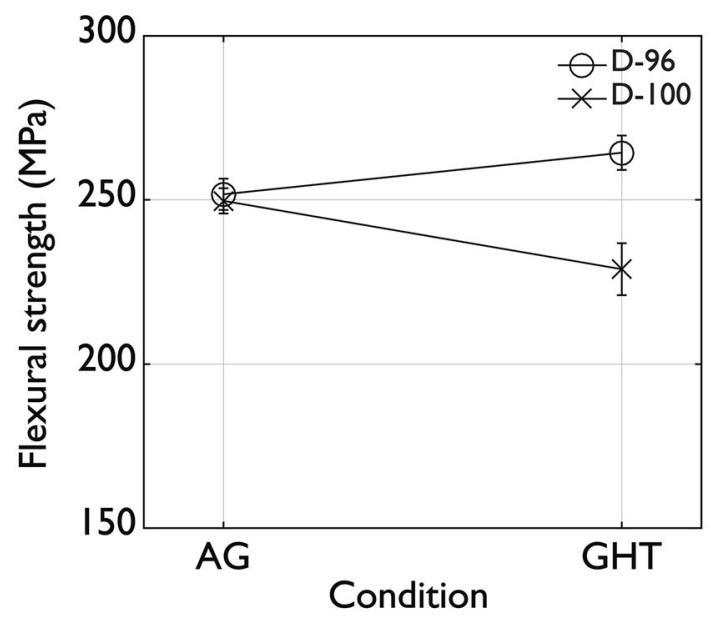

Fig. 6 Average flexural strengths (MPa) of D-96 AG, D-96 GHT, D-100 AG, and D-100 GHT standard test bars were observed in the non-uniform microstructures of both D-96 AG and D-100 AG joints made using 100- $\mu$ m-thick TICUSIL ${ }^{\circledR}$ preforms. These were an Ag-rich phase (Fig. 10a, H, 11c, O), a $\mathrm{Cu}$-rich phase (Fig. 10a, I, 11b, N), a reaction layer phase, and two $\mathrm{Cu}-\mathrm{Ti}$ phases (Fig. 10a, J and K, 11a, L and M).

The Ag-rich and Cu-rich phases in both D-96 AG and D100 AG joints made using $100-\mu$ m-thick TICUSIL ${ }^{\circledR}$ preforms had the same compositions as those $\mathrm{Ag}$-rich and $\mathrm{Cu}$-rich phases characterized earlier, in the joints made using $50-\mu \mathrm{m}$-thick TICUSIL $^{\circledR}$ preforms. These phases were observed throughout the microstructures of all brazed joints. However, the predominant phases in the microstructures of both D-96 AG and D-100 AG joints, made using 100- $\mu$ m-thick TICUSIL ${ }^{\circledR}$ preforms were $\mathrm{Cu}$-Ti rich (Fig. 10a, 11a).

The $\mathrm{Cu}$-Ti phases consisted of a micro-segregated composition with a core phase characterized as $\mathrm{Cu}_{4} \mathrm{Ti}_{3}$ (Fig. 10a, J, and $11 \mathrm{a}, \mathrm{L})$ and a surrounding shell phase characterized as $\mathrm{Cu}_{3} \mathrm{Ti}$ (Fig. 10a, K and 11a, M). Transition regions (Fig. 10b, 11b) were observed between the $\mathrm{Cu}-\mathrm{Ti}$ phases and Ag-rich globules (Fig. 10c, 11c) which were present at the very edges of the joints. The microstructures of these transition regions were similar to the microstructures of joints made using $50-\mu \mathrm{m}-$ thick TICUSIL ${ }^{\circledR}$ preforms. However, the presence of $\mathrm{Cu}-\mathrm{Ti}$ phases in the microstructure of alumina-to-alumina-brazed joints made using $\mathrm{Ag}-\mathrm{Cu}-\mathrm{Ti}$ alloys was not found to have been reported elsewhere.

3.5.3 Cu-Ti Phases. Braze outflow was observed to have occurred in all brazed joints, made using both 50- and 100- $\mu \mathrm{m}-$ thick TICUSIL ${ }^{\circledR}$ preforms. The percentage of braze outflow, relative to the TICUSIL ${ }^{\circledR}$ preform selected, was estimated to be $\sim 46 \%$ for both D-96 AG and D-100 AG joints made using the 100 - $\mu$ m-thick TICUSIL ${ }^{\circledR}$ preforms. This calculation was based on the $7 \times 5 \times 0.1 \mathrm{~mm}$ preform having completely filled the joint gap between two $8 \times 6 \mathrm{~mm}$ faying surfaces to produce a uniform brazed thickness of $39.0 \mu \mathrm{m}$.

The microstructure of the braze outflow in D-96 AG and D100 AG joints made using 50 - $\mu$ m-thick TICUSIL ${ }^{\circledR}$ preforms was observed to be similar to its appearance in the joint (Fig. 12a). However, the microstructure of the braze outflow in D-96 AG and D-100 AG joints made using 100- $\mu$ m-thick TICUSIL ${ }^{\circledR}$ preforms was observed to be different and consisted of Ag-rich globules (Fig. 12b).

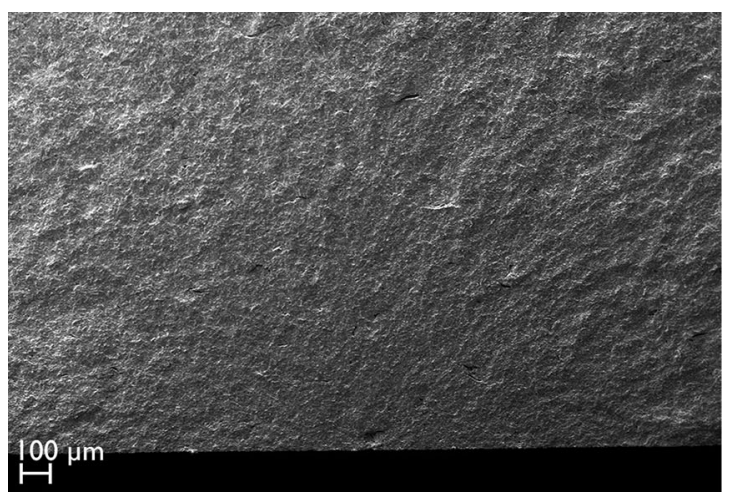

(a)

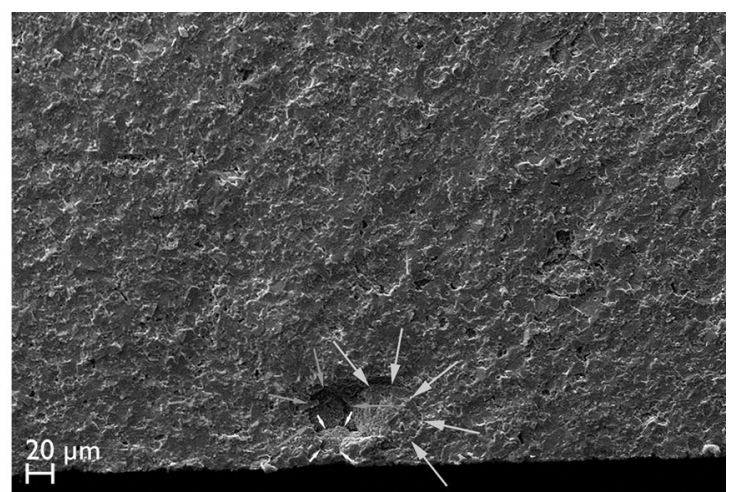

(b)

Fig. 7 SE images of the failure origin in the highest strength D-96 GHT standard test bar (286 MPa) showing a clustered processing defect which comprised a small group of sub-surface agglomerates (represented by arrows) close to the tensile surface (a) Lower magnification and (b) Higher magnification 
While the TICUSIL ${ }^{\circledR}$ composition remained constant as the preform thickness was increased from 50 to $100 \mu \mathrm{m}$, the total amount of $\mathrm{Ti}$ available relative to the alumina surfaces increased twofold (Fig. 8).

With a brazing temperature of $850{ }^{\circ} \mathrm{C}$ and dwell time of $10 \mathrm{~min}, \mathrm{a} \sim 1.7-\mu \mathrm{m}$-thick reaction layer formed in joints made using 50- $\mu$ m-thick TICUSIL ${ }^{\circledR}$ preforms. EDX elemental maps of the microstructures of these joints showed that almost no Ti remained in the $\mathrm{Ag}-\mathrm{Cu}$ braze interlayer. Therefore, the brazing temperature of $850^{\circ} \mathrm{C}$ was sufficient for the complete diffusion of Ti to the joint interfaces. With the same brazing cycle applied to joints made using $100-\mu \mathrm{m}$-thick TICUSIL $^{\circledR}$ preforms, however, a thicker $\sim 2.3 \mu \mathrm{m}$ reaction layer was observed. A significant amount of $\mathrm{Ti}$ was retained in the interlayer in the form of $\mathrm{Cu}$-Ti phases. As a result of using a thicker TICUSIL ${ }^{\circledR}$ preform, residual $\mathrm{Ti}$ which did not react at the interface formed $\mathrm{Cu}$-Ti phases in the braze interlayer. This is consistent with the excellent affinity $\mathrm{Ti}$ has with $\mathrm{Cu}$ (up to 67 wt.\% solubility at $1150{ }^{\circ} \mathrm{C}$ ) which is higher than the affinity $\mathrm{Ti}$ has with $\mathrm{Ag}$ (only 3 wt. $\%$ solubility at $\left.1150{ }^{\circ} \mathrm{C}\right)(\operatorname{Ref} 21)$.

The presence of $\mathrm{Cu}_{4} \mathrm{Ti}_{3}$ (core phase) and residual $\mathrm{Ti}$ in the braze interlayer may have led to further preferential formation of $\mathrm{Cu}_{3} \mathrm{Ti}$ (shell phase). This may have caused the separation of an Ag-rich phase similar to the way in which the miscibility gap in TICUSIL ${ }^{\circledR}$ has been reported to lead to the separation of an Ag-rich (Ag-27Cu-2Ti wt.\%) and a Cu-rich phase (Ag-66Cu$22 \mathrm{Ti}$ wt.\%) at $900{ }^{\circ} \mathrm{C}$ (Ref 6). Separation of an Ag-rich phase is also evident in the as-received braze foil as a $\sim 2-\mu \mathrm{m}$-thick layer around the $\mathrm{Cu}_{4} \mathrm{Ti}_{3}$ phase (Fig. 8b, C).

The flow of an Ag-rich phase across the alumina surface and toward the joint edges may have led to the formation of Ag-rich globules as any residual Ti present in the braze alloy diffused towards the joint interfaces. In other studies, the wetting and spreading of TICUSIL ${ }^{\circledR}$ across an alumina surface have been shown to be led by a Ti-depleted Ag-rich phase (Ref 1).

The Ag-rich outflow from the center of the joint can be considered to result in a deviation from the TICUSIL $^{\circledR}$ composition, leading to an increase in $\mathrm{Cu}$ content which may have further promoted the formation of $\mathrm{Cu}-\mathrm{Ti}$ phases. Studies have shown that as the $\mathrm{Ag}$ content decreases or the $\mathrm{Cu}$ content increases, in Ag-Cu-Ti alloys, the effect on $\mathrm{Ti}$ is to reduce its activity and increase its concentration in the interlayer (Ref 13, 22). The presence of a ductile Ag-rich phase at the joint edges may have also helped to improve the joint strength.

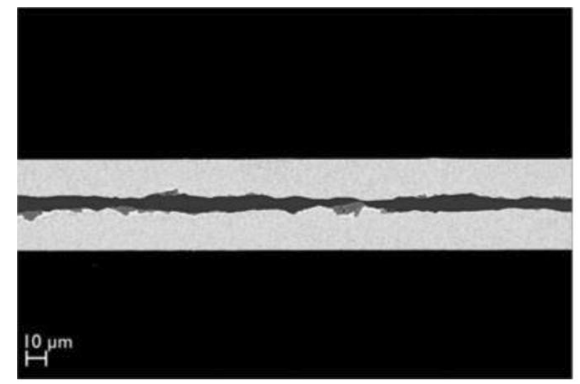

(a)

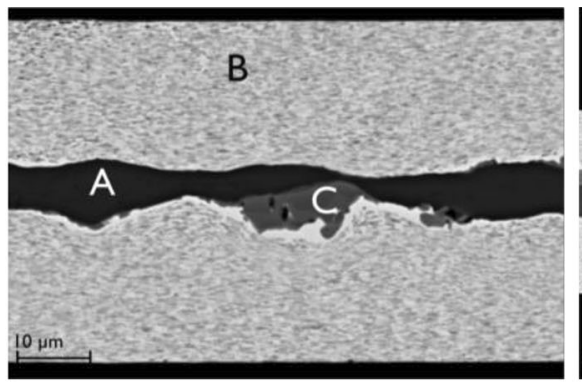

(b)

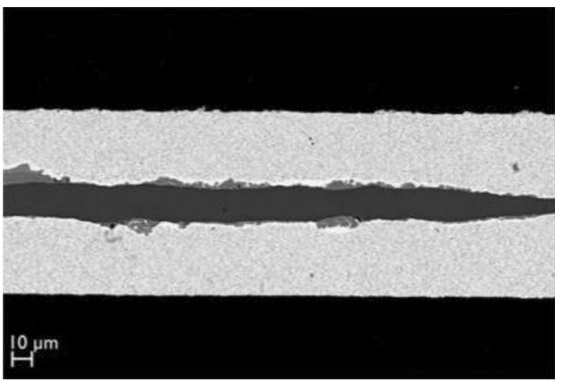

(c)

Fig. 8 BSE images of the as-received TICUSIL ${ }^{\circledR}$ foil with thicknesses of (a) $50 \mu \mathrm{m}$, (b) $50 \mu \mathrm{m}$ (high magnification), and (c) $100 \mu \mathrm{m}$

Table 3 Average chemical compositions (wt.\%) of phases in SEM images shown in Fig. 8, 9, and 11

\begin{tabular}{|c|c|c|c|c|}
\hline & Ag & $\mathbf{C u}$ & $\mathbf{T i}$ & Al \\
\hline$A^{*}$ & 0.2 & 0.3 & 99.5 & $\ldots$ \\
\hline $\mathrm{B}^{*}$ & 71.7 & 28.3 & $\ldots$ & $\ldots$ \\
\hline $\mathrm{C}^{*}$ & 3.5 & 36.2 & 60.3 & $\ldots$ \\
\hline $\mathrm{D}$ & 96.5 & 3.5 & $\ldots$ & $\ldots$ \\
\hline E & 5.6 & 93.9 & 0.5 & $\ldots$ \\
\hline $\mathrm{F}$ & $\ldots$ & 49.7 & 44.8 & 5.5 \\
\hline $\mathrm{G}$ & $\ldots$ & 46.4 & 47.6 & 6.0 \\
\hline $\mathrm{H}$ & 94.4 & 5.6 & $\cdots$ & $\cdots$ \\
\hline I & 6.1 & 93.3 & 0.6 & $\ldots$ \\
\hline $\mathrm{J} *$ & 4.0 & 62.6 & 33.4 & $\ldots$ \\
\hline $\mathrm{K}^{*}$ & 2.5 & 81.9 & 15.6 & $\ldots$ \\
\hline $\mathrm{L}$ & 3.80 & 62.4 & 33.8 & $\ldots$ \\
\hline $\mathrm{M}$ & 2.7 & 82.4 & 14.9 & $\ldots$ \\
\hline $\mathrm{N}$ & 5.4 & 92.6 & 2.0 & $\ldots$ \\
\hline $\mathrm{O}$ & 94.7 & 5.3 & $\ldots$ & $\ldots$ \\
\hline
\end{tabular}

Analysis performed by EDX and EPMA analysis, * denotes those made by EPMA analysis 


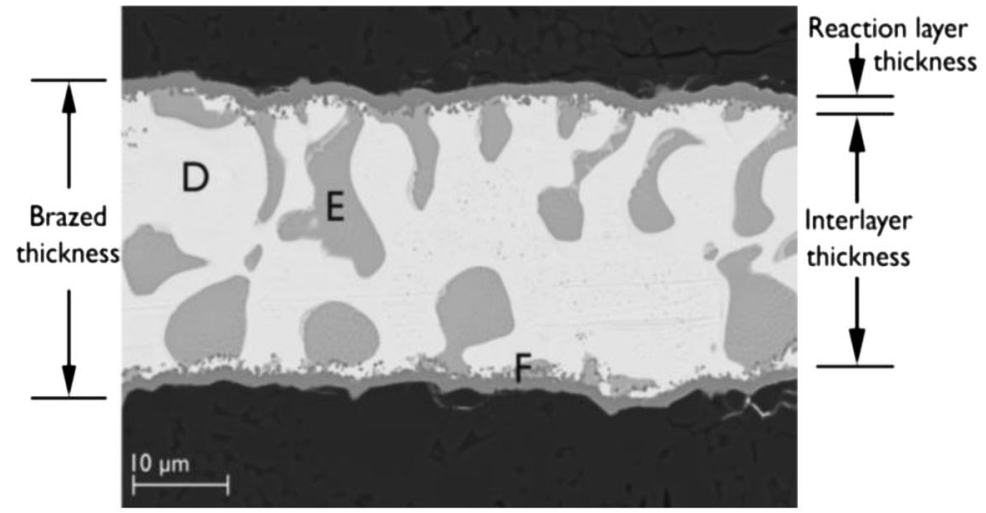

(a)

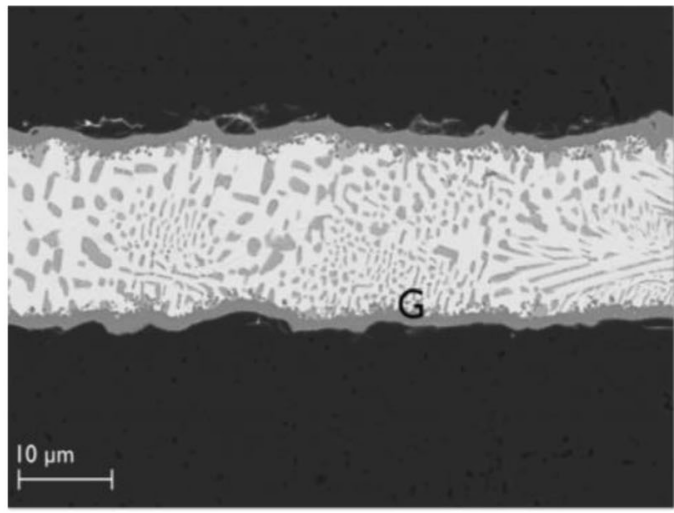

(b)

Fig. 9 BSE images of typical (a) D-96 AG and (b) D-100 AG-brazed joints made using 50- $\mu$ m-thick TICUSIL ${ }^{\circledR}$ preforms

Table 4 Properties of alumina-to-alumina-brazed joints made using TICUSIL ${ }^{\circledR}$ preforms

\begin{tabular}{|c|c|c|c|c|c|c|c|c|c|}
\hline $\begin{array}{l}\text { Alumina } \\
\text { grade }\end{array}$ & $\begin{array}{l}\text { Surface } \\
\text { condition }\end{array}$ & $\begin{array}{c}\text { Preform } \\
\text { thickness, } \\
\mu \mathrm{m}\end{array}$ & $\begin{array}{c}\text { Number of } \\
\text { specimens } \\
\text { characterized }\end{array}$ & $\begin{array}{c}\text { Reaction } \\
\text { layer thickness, } \\
\mu \mathrm{m}\end{array}$ & $\begin{array}{c}\text { Average } \\
\text { brazed joint } \\
\text { thickness, } \mu \mathrm{m}\end{array}$ & $\begin{array}{c}\text { Estimated } \\
\text { volume of braze } \\
\text { outflow, } \%\end{array}$ & $\begin{array}{c}\text { Specimens } \\
\text { mechanically } \\
\text { tested }\end{array}$ & $\begin{array}{c}\text { Joint } \\
\text { strength, MPa }\end{array}$ & $\begin{array}{c}\text { Failure } \\
\text { locations }\end{array}$ \\
\hline D-96 AG & As-ground & 50 & 1 & $1.7 \pm 0.1$ & $25.9 \pm 0.3$ & 29.0 & 4 & $136.1 \pm 14.4$ & Interface \\
\hline D-96 AG & As-ground & 100 & 3 & $2.3 \pm 0.1$ & $39.1 \pm 0.6$ & 46.4 & 4 & $238.3 \pm 30.7$ & Ceramic \\
\hline D-100 AG & As-ground & 50 & 1 & $1.6 \pm 0.1$ & $21.2 \pm 0.5$ & 41.9 & 4 & $163.0 \pm 11.7$ & Interface \\
\hline D-100 AG & As-ground & 100 & 2 & $2.2 \pm 0.1$ & $39.2 \pm 1.0$ & 46.2 & 4 & $199.5 \pm 18.6$ & Interface \\
\hline D-96 GHT & $\begin{array}{l}\text { Ground and } \\
\text { heat treated }\end{array}$ & 100 & 1 & $2.4 \pm 0.3$ & $57.1 \pm 5.6$ & 21.7 & 4 & $105.8 \pm 15.7$ & Interface \\
\hline
\end{tabular}

\subsection{Strength of Brazed Joints}

The average strengths of sets of four D-96 AG-brazed joints increased by $75 \%$, from 136 to $238 \mathrm{MPa}$ as the TICUSIL $^{\circledR}$ preform thickness increased from 50 to $100 \mu \mathrm{m}$. While all of the joints made using 50 - $\mu$ m-thick TICUSIL ${ }^{\circledR}$ preforms failed at the interface, those made using $100-\mu \mathrm{m}$-thick TICUSIL $^{\circledR}$ preforms failed in the ceramic at an average distance of $14 \mathrm{~mm}$ away from the joint. The joint strength of $238 \mathrm{MPa}$ was comparable to the average flexural strength of D-96 AG standard test bars of $252 \mathrm{MPa}$.

The average strengths of sets of four D-100 AG-brazed joints increased by $22 \%$, from 163 to $199 \mathrm{MPa}$ as the TICUSIL $^{\circledR}$ preform thickness increased from 50 to $100 \mu \mathrm{m}$. All of the D-100 AG joints failed at the interface.

As the TICUSIL ${ }^{\circledR}$ preform thickness increased from 50 to $100 \mu \mathrm{m}$, the average brazed thickness increased from 25.9 to $39.1 \mu \mathrm{m}$ in D-96 AG joints and from 21.2 to $39.2 \mu \mathrm{m}$ in D-100 AG joints. This increase in brazed joint thickness may have provided greater ductility, resulting in better accommodation of TIRS and an associated increase in joint strength. This result was consistent with other studies, whereby the average shear strength of alumina-to-alumina-brazed joints was reported to increase when two layers of a variety of $\mathrm{Ag}-\mathrm{Cu}-\mathrm{Ti}$ braze alloys were used in comparison to just one layer (Ref 23). Furthermore, in studies relating to alumina-to-metal-brazed joints, an increase in brazed joint thickness has also been shown to improve joint strength (Ref 7).

As well as from the increase in brazed joint thickness, an improvement in joint strength may have also resulted from the formation of $\mathrm{Cu}$-Ti phases which may have lowered the CTE of the interlayer and reduced the CTE mismatch at the joint interfaces, resulting in a reduction of TIRS. The reaction layer $\left(\mathrm{Ti}_{3} \mathrm{Cu}_{3} \mathrm{O}\right)$, also rich in $\mathrm{Cu}-\mathrm{Ti}$, has an intermediate CTE $\left(15.1 \times 10^{-6} /{ }^{\circ} \mathrm{C}\right)$ relative to the $\mathrm{Ag}-\mathrm{Cu}$ braze interlayer and alumina and grades the mismatch in CTE between them (Ref 13).

As the TICUSIL $^{\circledR}$ preform thickness increased from 50 to $100 \mu \mathrm{m}$, the average reaction layer thickness increased from 1.7 to $2.3 \mu \mathrm{m}$ in D-96 AG joints and from 1.6 to $2.2 \mu \mathrm{m}$ in D100 AG joints. An increase of $\sim 35 \%$ in the reaction layer thickness occurred as a direct result of increased TICUSIL ${ }^{\circledR}$ preform thickness in a fixed brazing cycle. This showed that the TICUSIL $^{\circledR}$ preform thickness can influence the reaction layer thickness in addition to other variables such as the $\mathrm{Ti}$ concentration, peak brazing temperature and dwell time which have also been shown to affect the reaction layer thickness and resulting joint strength (Ref 6,10$)$.

It can be summarized that there are three factors, affected by the TICUSIL ${ }^{\circledR}$ preform thickness, which can in turn affect the strength of alumina-to-alumina-brazed joints made using 


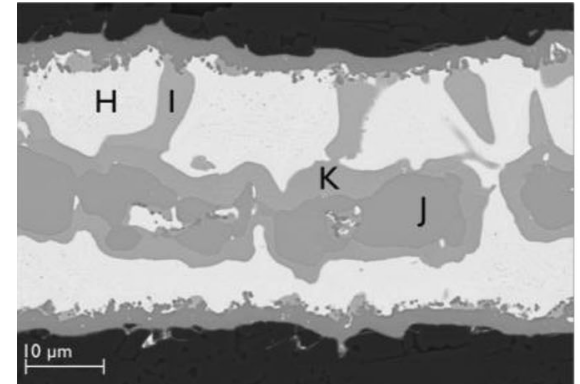

(a)

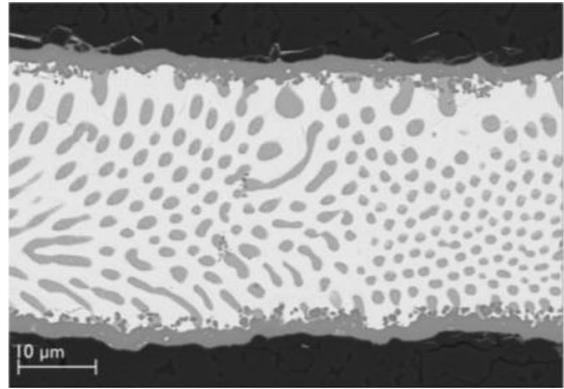

(b)

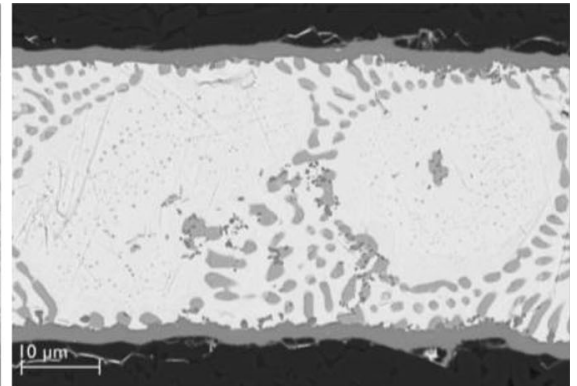

(c)

Fig. 10 BSE images of typical regions in D-96 AG-brazed joints made using 100- $\mu \mathrm{m}$-thick TICUSIL ${ }^{\circledR}$ preforms (a) Cu-Ti phases, (b) Transition regions, and (c) Ag-rich globules

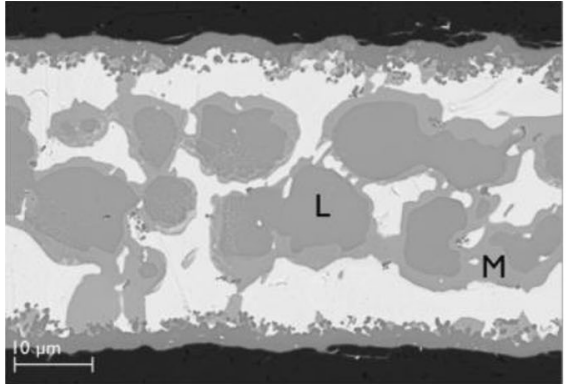

(a)

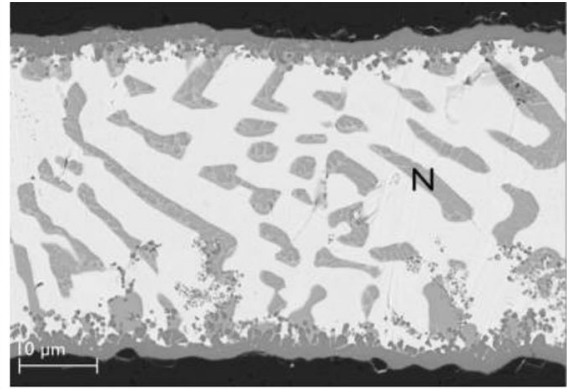

(b)

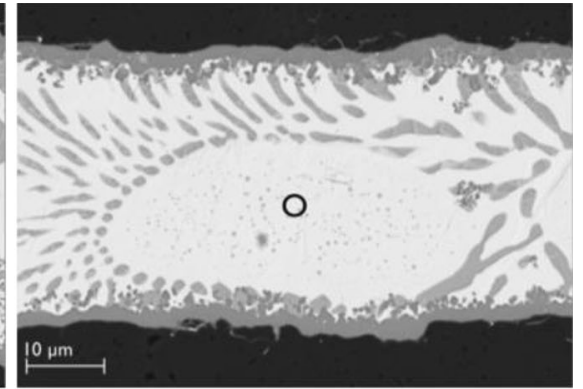

(c)

Fig. 11 BSE images of typical regions in D-100 AG-brazed joints made using 100- $\mu$ m-thick TICUSIL ${ }^{\circledR}$ preforms (a) Cu-Ti phases, (b) Transition regions, and (c) Ag-rich globules

TICUSIL $^{\circledR}$ preforms. These are the (1) brazed joint thickness, (2) $\mathrm{Cu}$-Ti phases in the braze interlayer and Ag-rich outflow, and (3) reaction layer thickness. It appears that all of these factors can be affected by the TICUSIL $^{\circledR}$ preform thickness which increases the amount of $\mathrm{Ti}$ available relative to the alumina surfaces (Fig. 13).

D-96 AG joints made using $100-\mu$ m-thick TICUSIL $^{\circledR}$ preforms outperformed those made using D-100 AG as a result of the difference in alumina composition. D-96 AG had a secondary phase that was predominantly composed of Si. It was postulated that $\mathrm{Si}$ interaction with the reaction layer may have also affected the joint strength. Elemental profiles across the interfaces of joints made using $100-\mu$ m-thick TICUSIL $^{\circledR}$ preforms were measured using EPMA (Fig. 14) and Si was observed at the reaction layers of D-96 AG joints made using $100 \mu \mathrm{m}$ TICUSIL $^{\circledR}$ preforms (Fig. 14a). This result was consistent with other studies which have shown that $\mathrm{Si}$ as a secondary phase in alumina can interact at the alumina/Ag-CuTi interface (Ref 8). The extent of Si interaction at the alumina/ $\mathrm{Ag}-\mathrm{Cu}-\mathrm{Ti}$ interface, however, and its contribution to improved joint strength requires further study. At the interfaces of D-100 AG joints made using $100 \mu \mathrm{m}$ TICUSIL ${ }^{\circledR}$ preforms no Si was observed.

The average strength of a set of four D-96 GHT-brazed joints made using 100 - $\mu \mathrm{m}$-thick TICUSIL $^{\circledR}$ preforms was $106 \mathrm{MPa}$. All D-96 GHT joints failed at the joint interface. Despite the $5.2 \%$ increase in the average flexural strength of $\mathrm{D}$ 96 AG standard test bars following heat treatment, once brazed, a $55.5 \%$ reduction in the average joint strength was observed for D-96 GHT joints made using $100 \mu \mathrm{m}$ TICUSIL ${ }^{\circledR}$ preforms (Fig. 15). These results are contrary to the literature (Table 1) in which post-grinding heat treatment at near-sintering temperatures is used to improve the strength of alumina prior to brazing, and in order to improve the resulting joint strength.

The brazed joint thickness of D-96 GHT-brazed joints was observed to be highly non-uniform. This may have also contributed to the degradation in strength observed. An average brazed joint thickness of $57.1 \mu \mathrm{m}$ was measured. This was much thicker than the brazed joint thicknesses of D-96 AG and D-100 AG joints made using $100 \mu \mathrm{m}$ TICUSIL $^{\circledR}$ preforms, and characterization of further specimens is required. The average reaction layer thickness, however, of $2.4 \mu \mathrm{m}$ was similar to the average reaction layer thicknesses of D-96 AG and D100 AG joints, made using $100 \mu \mathrm{m}$ TICUSIL ${ }^{\circledR}$ preforms. The joint microstructure was also composed of the $\mathrm{Cu}$-Ti phases previously discussed.

Braze penetration into a fissured D-96 GHT surface was observed (Fig. 16a). The fissured surface of D-96 GHT may have been caused by the retraction of liquid phase away from the alumina surface during the post-grinding heat treatment. As a result, braze was observed to be occupying intergranular regions characteristic of where the secondary phase may have migrated away from (Fig. 16b). Fractography revealed that failure was initiated at the sub-surface region of alumina where braze penetration may have generated TIRS and structurally weakened the D-96 GHT joints (Fig. 16c). Due to the non- 


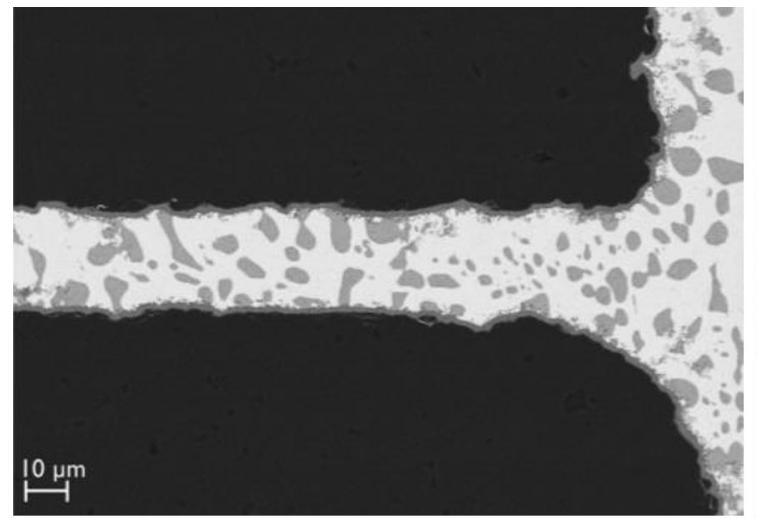

(a)

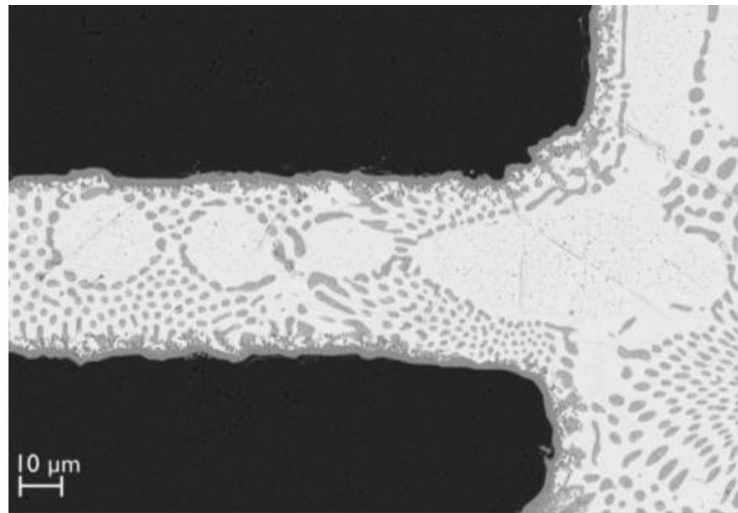

(b)

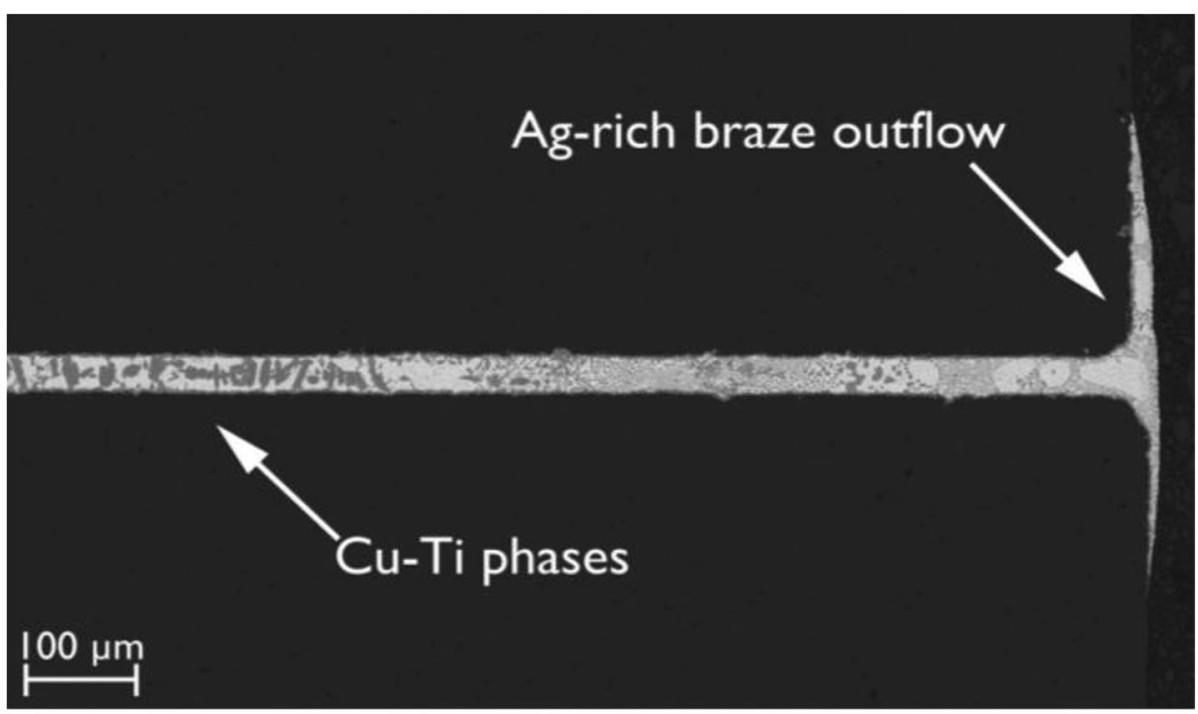

(c)

Fig. 12 BSE images of typical braze outflow in (a) D-96 AG joints made using 50- $\mu$ m-thick TICUSIL ${ }^{\circledR}$ preforms, (b) D-100 AG joints made using 100- $\mu$ m-thick TICUSIL ${ }^{\circledR}$ preforms, and (c) D-96 AG joints made using 100- $\mu$ m-thick TICUSIL ${ }^{\circledR}$ preforms (low magnification)

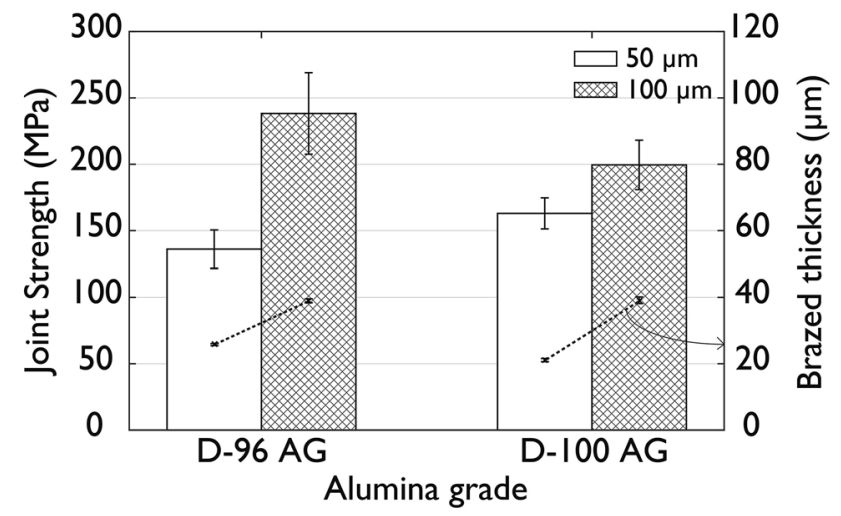

Fig. 13 Average joint strengths (MPa) and brazed joint thicknesses $(\mu \mathrm{m})$ of D-96 AG and D-100 AG joints made using 50- and 100$\mu \mathrm{m}$-thick TICUSIL ${ }^{\circledR}$ preforms uniform brazed joint thickness and braze penetration observed in the D-96 GHT-brazed joints, the effect of post-grinding heat treatment on joint strength requires further investigation.

\section{Conclusions}

The effect of post-grinding heat treatment and $\mathrm{Ag}-\mathrm{Cu}-\mathrm{Ti}$ preform thickness on the strength of alumina-to-alumina-brazed joints made using 96.0 (D-96) and 99.7 (D-100) wt.\% $\mathrm{Al}_{2} \mathrm{O}_{3}$ has been studied.

1. Post-grinding heat treatment did not affect the surface roughness of either grades of alumina. It did, however, lead to a $5.2 \%$ increase in the average flexural strength of D-96 AG test bars and an 8.4\% decrease in the average flexural strength of D-100 AG test bars. 


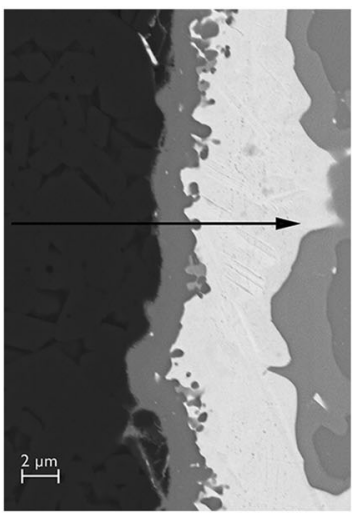

(a)

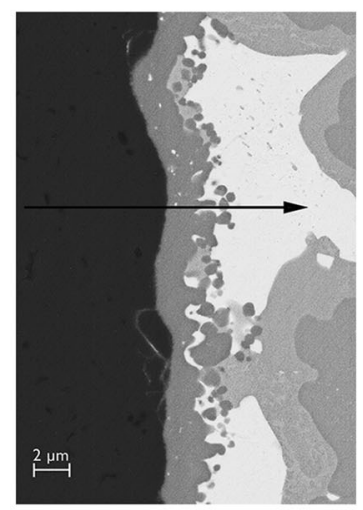

(b)

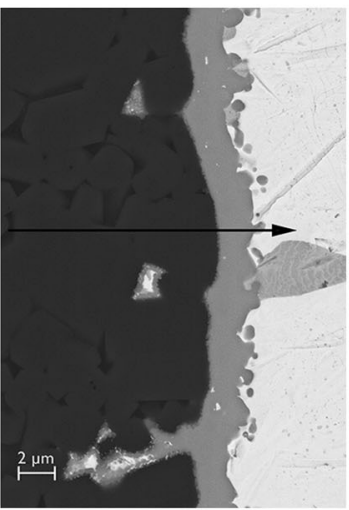

(c)
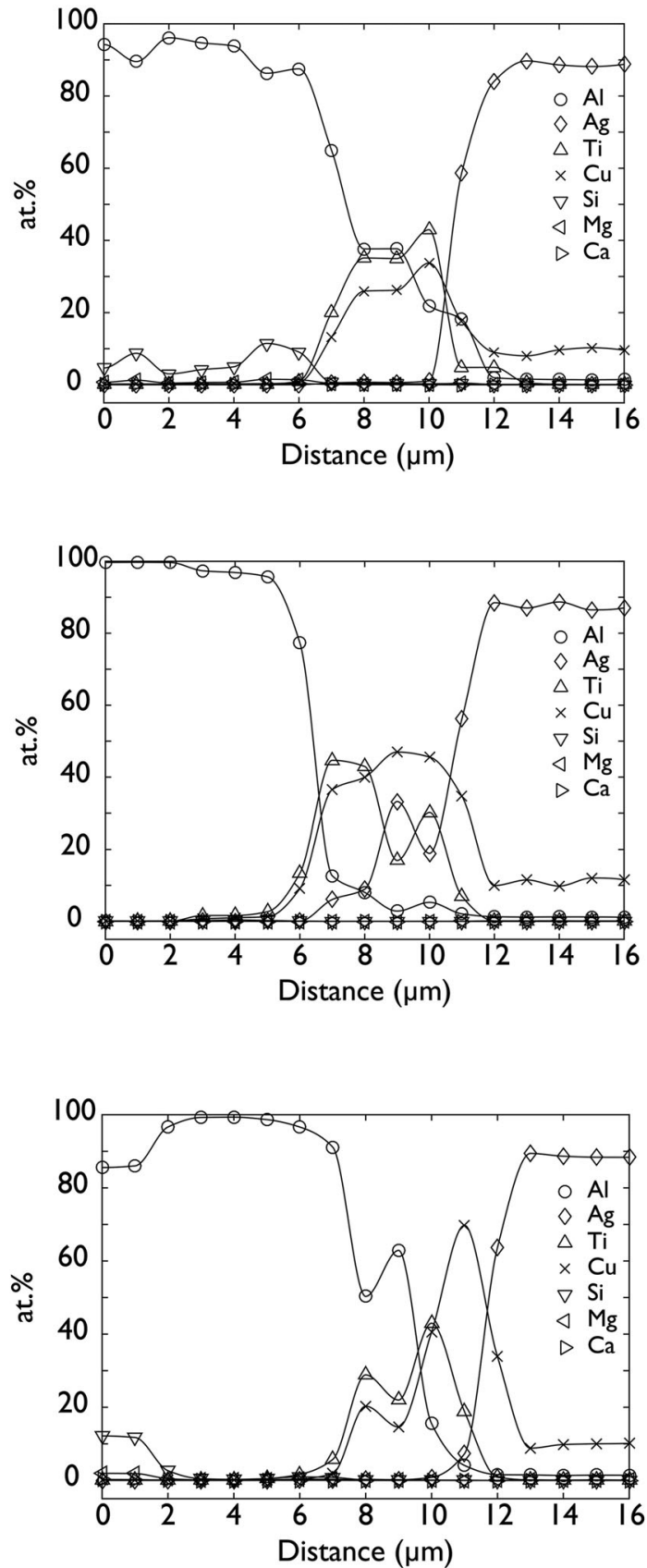

Fig. 14 BSE images and elemental profiles (at.\%) across alumina/TICUSIL ${ }^{\circledR}$ interfaces of (a) D-96 AG, (b) D-100 AG, and (c) D-96 GHTbrazed joints made using $100-\mu \mathrm{m}$-thick TICUSIL $^{\circledR}$ preforms 


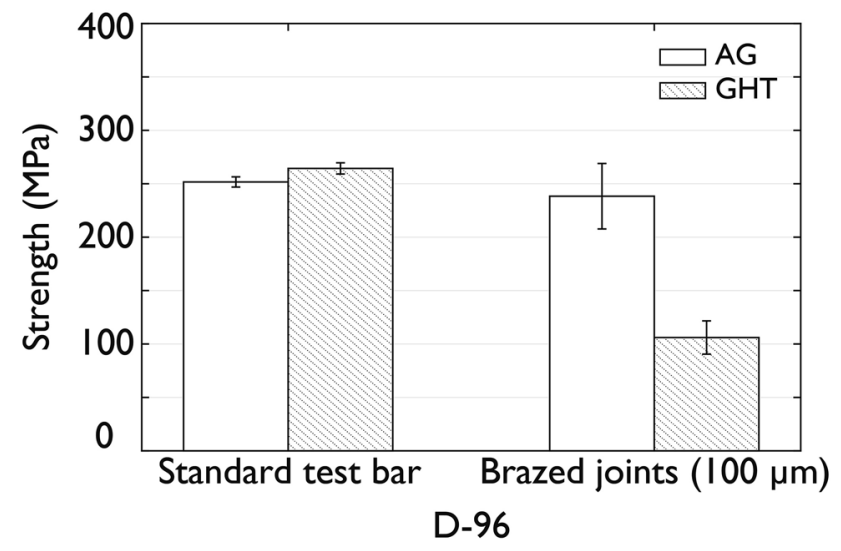

Fig. 15 A comparison of the average flexural strengths (MPa) of D-96 AG and D-96 GHT standard test bars and average strengths (MPa) of D-96 and D-96 GHT-brazed joints made using $100-\mu \mathrm{m}$ thick TICUSIL ${ }^{\circledR}$ preforms

2. An increase in the TICUSIL ${ }^{\circledR}$ preform thickness, from 50 to $100 \mu \mathrm{m}$, led to an increase in the average strengths of D-96 AG and D-100 AG joints by 75 and $22 \%$, respec- tively. For brazed joints made using $100 \mu \mathrm{m}$ thick TICUSIL ${ }^{\circledR}$, D-96 AG-brazed joints outperformed D-100 AGbrazed joints. The increase in TICUSIL ${ }^{\circledR}$ preform thickness also led to an increase in the average reaction layer thickness, from 1.7 to $2.3 \mu \mathrm{m}$ in both D-96 AG and D100 AG-brazed joints.

3. The average flexural strength of D-96 AG standard test bars was $252 \mathrm{MPa}$ and brazed joints made using D-96 AG and $100-\mu \mathrm{m}$-thick TICUSIL $^{\circledR}$ preforms achieved an average joint strength of $238 \mathrm{MPa}$ with failure consistently occurring in the ceramic. EPMA detected the presence of $\mathrm{Si}$ at the brazed interface.

4. At a brazing temperature of $850{ }^{\circ} \mathrm{C}$, complete diffusion of $\mathrm{Ti}$ to the interfaces was observed in joints made using 50 - $\mu \mathrm{m}$-thick TICUSIL ${ }^{\circledR}$ preforms. As the TICUSIL ${ }^{\circledR}$ preform thickness was increased to $100 \mu \mathrm{m}$, excess $\mathrm{Ti}$ in the braze interlayer and non-uniform Ag-rich outflow led to the formation of $\mathrm{Cu}-\mathrm{Ti}$ phases in the joint microstructure.

5. Contrary to the literature, post-grinding heat treatment was observed to degrade the average joint strength of D96 GHT-brazed test bars. The average joint strength decreased from 238 to $106 \mathrm{MPa}$. This is being investigated further in on-going work.

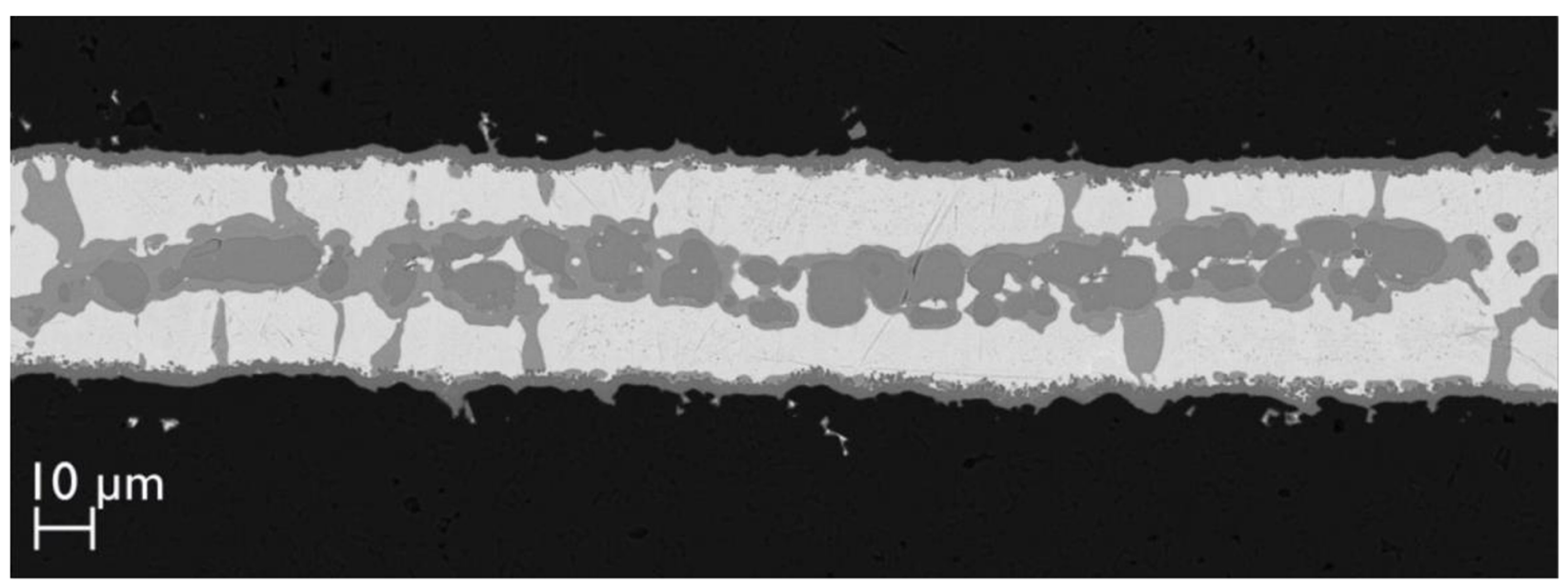

(a)

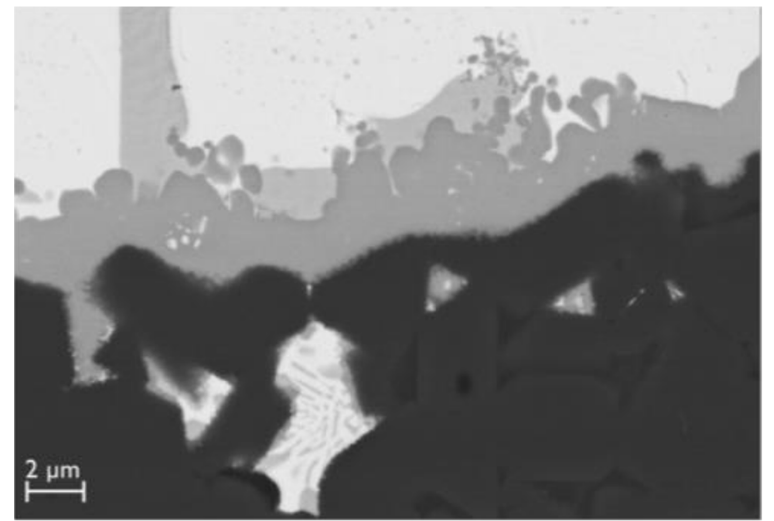

(b)

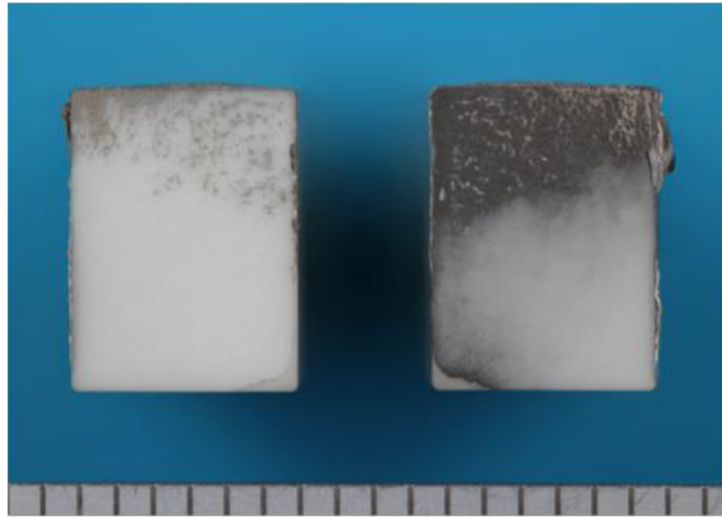

(c)

Fig. 16 (a) BSE image of a typical D-96 GHT-brazed joint made using a 100- $\mu$ m-thick TICUSIL ${ }^{\circledR}$ preform, (b) BSE image of a typical D-96 GHT-brazed joint made using a $100-\mu \mathrm{m}$-thick TICUSIL ${ }^{\circledR}$ preform (higher magnification), and (c) Fractured surfaces of a D-96 GHT-brazed joint made using a $100-\mu \mathrm{m}$-thick TICUSIL ${ }^{\circledR}$ preform 


\section{Acknowledgment}

We acknowledge the EPSRC and TWI Ltd (EP/K504270/1) for the financial support for this study. We are grateful to Dr. R. Morrell, National Physical Laboratory (NPL) for discussions relating to this work and L. Mills, TWI Ltd for assistance with drawings.

\section{Open Access}

This article is distributed under the terms of the Creative Commons Attribution 4.0 International License (http://creativecommons. org/licenses/by/4.0/), which permits unrestricted use, distribution, and reproduction in any medium, provided you give appropriate credit to the original author(s) and the source, provide a link to the Creative Commons license, and indicate if changes were made.

\section{References}

1. D.B. Conquest, "Brazing of Alumina for High Temperature Applications," Ph.D. thesis, Cambridge University, 2003

2. N. Eustathopoulos, Dynamics of Wetting in Reactive Metal/Ceramic Systems, Acta Mater, 1998, 46(7), p 2319-2327

3. A. Belenky and D. Rittel, Static and Dynamic Flexural Strength of 99.5\% Alumina: Relation to Surface Roughness, Mech. Mater., 2012, 54, p 91-99

4. T.W. Liao, K. Li, and K. Breder, Flexural Strengths of Ceramics Ground Under Widely Different Conditions, J. Mater. Process. Technol., 1997, 70(1), p 198-206

5. H.P. Kirchner, R.M. Gruver, and R.E. Walker, Strength Effects Resulting from Simple Surface Treatments, The Science of Ceramic Machining and Surface Finishing, Nov 2-4, 1970 (Gaithersburg, MD, USA), p 353-363

6. R. Voytovych, F. Robaut, and N. Eustathopoulos, The Relation Between Wetting and Interfacial Chemistry in the CuAgTi/Alumina System, Acta Mater., 2006, 54, p 2205-2214

7. H. Mizuhara, E. Huebel, and T. Oyama, High-Reliability Joining of Ceramic to Metal, Am. Ceram. Soc. Bull., 1989, 68(9), p 1591-1599
8. M. Ali, K.M. Knowles, P.M. Mallison, and J.A. Fernie, Microstructural Evolution and Characterisation of Interfacial Phases in $\mathrm{Al}_{2} \mathrm{O}_{3} / \mathrm{Ag}-\mathrm{Cu}-$ $\mathrm{Ti} / \mathrm{Al}_{2} \mathrm{O}_{3}$ Braze Joints, Acta Mater, 2015, 96, p 143-158

9. K.-L. Lin, M. Singh, and R. Asthana, Interfacial Characterization of Alumina-to-Alumina Joints Fabricated Using Silver-Copper-Titanium Interlayers, Mater. Charact., 2014, 90, p 40-51

10. H. Hongqi, The Influence of Brazing Conditions on Joint Strength in $\mathrm{Al}_{2} \mathrm{O}_{3} / \mathrm{Al}_{2} \mathrm{O}_{3}$ Bonding, J. Mater. Sci., 1994, 24, p 5041-5046

11. C.-C. Lin, R.-B. Chen, and R.-K. Shiue, A Wettability Study of Cu/Sn/ Ti Active Braze Alloys on Alumina, J. Mater. Sci., 2001, 36, p 21452150

12. A.H. Carim and C.H. Mohr, Brazing of Alumina with $\mathrm{Ti}_{4} \mathrm{CU}_{2} \mathrm{O}$ and $\mathrm{Ti}_{3} \mathrm{CU}_{3} \mathrm{O}$ Interlayers, Mater. Lett., 1997, 33, p 195-199

13. S. Mandal, A.K. Ray, and A.K. Ray, Correlation Between the Mechanical Properties and the Microstructural Behaviour of $\mathrm{Al}_{2} \mathrm{O}_{3}$ (Ag-Cu-Ti) Brazed Joints, Mater. Sci. Eng., 2004, A 383, p 235-244

14. Standard Test Method for Flexural Strength of Advanced Ceramics at Ambient Temperature, C1161-13, ASTM, 2013, p 1-19

15. H.P. Kirchner and R.M. Gruver, The Elevated Temperature Flexural Strength and Impact Resistance of Alumina Ceramics Strengthened by Quenching, Mater. Sci. Eng., 1974, 13, p 63-69

16. D. Galusek, L. Baca, and P. Sajgalik, The Role of Glass in AluminaBased Engineering Ceramics, unpublished, Institute of Inorganic Chemistry, Slovak Academy of Sciences, Dubravska Cesta 9, 84236 Bratislava, Slovak Republic

17. R. Morrell, National Physical Laboratory (NPL), Private Communication

18. S. Nakamura, S. Tanaka, Z. Kato, and K. Uematsu, StrengthProcessing Defects Relationships based on Micrographic Analysis and Fracture Mechanics in Alumina Ceramics, J. Am. Ceram. Soc., 2009, 92(3), p 688-693

19. N. Karlsson, Metallic Oxides with the Structure of High-Speed Steel Carbide, Nature, 1951, 168, p 558

20. G.P. Kelkar and A.H. Carim, Synthesis, Properties, and Ternary Phase Stability of $\mathrm{M}_{6} \mathrm{X}$ Compounds in the Ti-Cu-O System, J. Am. Ceram. Soc., 1993, 76(7), p 1815-1820

21. D.M. Jacobson, G. Humpston, Principles of Brazing, ASM International, 2005

22. J.J. Pak, M.L. Santella, and R.J. Fruehan, Thermodynamics of Ti in Ag-Cu Alloys, Metall. Trans. B, 1990, 21B, p 349-355

23. D. Janickovic, P. Sebo, P. Duhaj, and P. Svec, The Rapidly Quenched Ag-Cu-Ti Ribbons for Active Joining of Ceramics, Mater. Sci. Eng. A., 2001, 304-306, p 569-573 